\title{
REgiONAL DIFFERENCES IN REVENUES FroM LOCAL TAXES \\ IN COMPARISON TO THE SOCIO-ECONOMIC LEVEL OF THE REgIONS OF THE SLOVAK REPUbliC
}

\section{Filip Flaška ${ }^{1}$, Zuzana Rigová ${ }^{2}$, Stanislav Kološta $^{3}$, Katarína Liptáková 4}

\begin{abstract}
The aim of the article is to reveal regional differences in revenues from local taxation and to compare the development of local government taxation ratios with selected socio-economic indicators within the NUTS III regions in the Slovak Republic. The paper points out the regional differences in local tax revenues in relation to total tax revenues, own current revenues, and total current expenditures with regard to the socio-economic level of the regions. We measure regional disparities through the coefficient of variation and the socio-economic level of regions through the composite index created from selected socioeconomic indicators of the respective regions. Results indicate that the social and economic performance of regions had an impact on revenues from taxation by local governments. We observe a declining trend of the monitored indicators from west to north-east of the country.
\end{abstract}

\section{Keywords}

Local Taxes, Local Governments, Regional Differences, Socio-Economic Indicators

\section{Introduction}

The measurement of socio-economic disparities in self-governing regions (i.e. in NUTS III regions) and local governments in the Slovak Republic were discussed by several authors (e.g. Flaška, Rigová, 2020; Čapková, Flaška, 2018; Kološta, 2016; Žárska, Ferčíková, 2015; Flaška, Kološta, Bolcárová, 2014). The issue of the relationship between tax revenues of

\footnotetext{
${ }^{1}$ Matej Bel University in Banská Bystrica, Tajovského 10, 97590 Banská Bystrica, Slovakia. E-mail: filip.flaska@umb.sk.

${ }^{2}$ Matej Bel University in Banská Bystrica, Tajovského 10, 97590 Banská Bystrica, Slovakia. E-mail: zuzana.rigova@umb.sk.

${ }^{3}$ Matej Bel University in Banská Bystrica, Tajovského 10, 97590 Banská Bystrica, Slovakia. E-mail: stanislav.kolosta@umb.sk.

${ }^{4}$ Matej Bel University in Banská Bystrica, Kuzmányho 1, 97401 Banská Bystrica, Slovakia. E-mail: katarina.liptakova@umb.sk.
} 
local governments and selected socio-economic indicators in NUTS III regions using a data set for individual governments in NUTS III regions in the Slovak Republic was not, to our knowledge, the subject of more detailed research. The availability of extensive and detailed data files of the DataCentre, which serves as an information centre for the Ministry of Finance of the Slovak Republic, enabled the examination of these mutual relations with reference to regional differentiations. We assumed that a partial review of this area will bring useful information for a better understanding of the context of the effects of socio-economic development in relation to selected tax indicators of local governments in NUTS III regions in Slovakia to obtain an alternative view of regional disparities. Thematically, the study examines the fiscal and socio-economic relations of local governments.

The aim of the article is to reveal regional differences in revenues from local taxation and to compare the development of local government taxation ratios with selected socioeconomic indicators within the NUTS III regions in the Slovak Republic. We measure regional disparities through the coefficient of variation and the socio-economic level of regions through the composite index created from selected socio-economic indicators of the respective regions. We focused on the investigation of the trend within the share of local taxes in the total tax revenues of local governments, the share of local taxes in own current income, and the share of local taxes in total expenditures in the years 2010 to 2019 in all 2890 local governments divided by NUTS III regions. The main motivation is to bring useful information for a better understanding of the context of the effects of socio-economic development in relation to selected tax indicators of local governments in NUTS III regions in Slovakia to obtain an alternative view of regional disparities. Currently in Slovakia runs is a broader political debate about raising local tax rates to increase municipal incomes due to growing expenditure needs. This study brings interesting results useful for decisions and policymakers. The article is structured as follows: section II contains theoretical background, section III data and methodology, in section IV we discuss results, and section $\mathrm{V}$ consists of conclusions.

\section{Theoretical Background}

Local governments most often finance their public expenditures via a mix of own-source revenues and grants from higher layers of government (Holm-Hadulla, 2020). Dependence on local taxes (especially from property taxes) as a source of local government revenue varies across jurisdictions depending upon many factors, such as the expenditure responsibilities assigned to local governments, the other revenues available to them (such as intergovernmental transfers, user fees, and other taxes), the degree of freedom local governments have with respect to property taxation, the size and growth of the tax base available to them, and their willingness and ability to enforce such taxes (Bird, Slack, 2002). The problem of adequate financing of local governments may be exacerbated by the spatial inequality of economic growth and prosperity of regions, which may deepen differences in the ability to generate comparable revenues (not only tax) between local governments and thus the ability to finance their current expenditures. These arguments are also used against the delegation of excessive local tax autonomy in the case of efforts to increase the degree of decentralization of revenue resources in relation to assigned expenditure responsibilities. 
In many countries, some of these problems have been addressed by reducing the role of local taxes and increasing the share of transfers from central government in local government revenues (Ahmad, Tanzi, Gao, 1995).

Tax revenues are an important source of revenue for local governments in Slovakia, and these revenues generate about half of their total revenues. A significant source of tax revenues of Slovak local governments is the income from share tax (personal income tax), which has the nature of transfers. Another important source of tax revenue for local governments is revenue from local taxes. The legislation allows local governments to collect eight local taxes. Local taxes that can be imposed by local governments in the Slovak Republic are property tax, dog tax, public space use tax, accommodation tax, vending machine tax, non-winning gaming machine tax, entry fee and motor vehicle stay in the historic part of the city, tax on nuclear facilities. The property tax has a decisive position among them, in terms of the amount of income generated.

Property taxes are levied by local governments and they obviously act as a main support to local autonomy. The extent to which such autonomy is either desired or attained is very country-specific (Bird, Slack, 2002).

Compared to income from share taxes, which are redistributed on the basis of a statutory formula and local governments are not autonomous in determining the rate and method of share tax redistribution, i.e. they are determined by their central level, Slovak local governments in the case of local taxes have a relatively high degree of tax autonomy in setting rates. This creates more room for differentiation in revenues from these taxes between individual governments (Sopkuliak, 2017).

In Slovakia, there are local governments of different size categories, with different size cadastral areas, with different asset structure, different population composition, with different representation of business activities and number of companies, different structure of the tax base for local taxes. In connection with the diversity of the tax base and the inconsistency of local governments in tax efforts (the use of tax autonomy) in local taxes, also affected by the diverse economic prosperity of regions, differences may arise in the amount of revenue generated from local taxes. Our goal was to investigate the possible relationships between local government tax revenues and socio-economic indicators at the regional level.

In the analysis, we focused on examining selected indicators in the field of tax revenues in the conditions of Slovak local governments in terms of their regional affiliation within the NUTS III regions. Slovakia is not one of the most decentralized countries in the world (in such countries the share of local government finances in public finances is even 50\%), but it is a decentralized country (the share of local government finances in public finances is less than a fifth) and especially since 2005 more expenditure responsibilities in the state administration and the system of their financing has changed with the strengthening of the role of local taxes and the increase of tax autonomy. In the first part of the article, we used selected indicators to point out the differences in local tax revenues between local governments according to their regional affiliation. 
Previous research (Liptáková, Rigová, 2021; Flaška, Rigová, 2020; Rigová, Flaška, Kološta, 2020) motivated us to further investigate the mutual relations between the tax revenues of local governments and socio-economic indicators at the regional level. This type of studies in the conditions of the Slovak Republic is rare or absent and could be of benefit to the scientific community as well as policymakers at local and regional level.

\section{Objective, Methodology and Data}

The aim of the article is to reveal regional differences in revenues from local taxation and to compare development of local government taxation ratios with selected socio-economic indicators within the NUTS III regions in the Slovak Republic. Slovak NUTS III regions are presented in the analysis with abbreviation of the region BA - Bratislavský, TT Trnavský, TN - Trenčiansky, NT - Nitriansky, ZA - Žilinský, BB - Banskobystrický, PO - Prešovský, and KE - Košický region.

We quantify taxation indicators by three ratios expressing local tax revenues in relation to total tax revenues, own current revenues and total current expenditures:

$$
\begin{aligned}
& \text { Ratio1 }=\sum \text { LTR } / \sum \text { TTR } \\
& \text { Ratio2 }=\sum \text { LTR } / \sum \text { OCR } \\
& \text { Ratio3 }=\sum \text { LTR } / \sum \text { TCE }
\end{aligned}
$$

where LTR represent local tax revenues, TTR total tax revenues, OCR own current revenues and TCE are total current expenditures aggregated for all local governments belonging to individual NUTS III regions. We monitor their development in the years 2010 to 2019. Given the above starting points of the issue, we consider the selected ratios to be adequate for our analysis. These indicators have a useful informative value when comparing them across local governments within different regions.

The data base for the calculation of Ratio1 to 3 are data from Slovak local governments from financial statements on the implementation of the budget of the public administration entity (FIN 1-04) - part of revenues and expenditures provided by DataCentre, which in Slovakia acts as an information source under the Ministry of Finance. All local governments in the Slovak Republic are obliged to send data in accordance with the relevant regulations and measures to the information centres through financial statements. We requested the reported data for all 2890 local governments of the Slovak Republic from the DataCentre according to the specification defined by us according to the regional affiliation of local governments. We obtained socio-economic indicators for NUTS III regions from publicly available sources from the DataCube database of the Statistical Office of the Slovak Republic.

To measure regional differences between NUTS III regions in the Slovak Republic in 2010 and 2019 in Ratio1-3 indicators, we use the coefficient of variation (VK) calculated according to the relationship (Hindls, Hronová, Seger, 2004, p. 42): 


$$
\mathrm{VK}=\frac{S_{x}}{\bar{X}}
$$

expressing the ratio of the standard deviation $\left(S_{x}\right)$ and the arithmetic mean of the indicator $(\bar{X})$. The coefficient of variation is one of the basic indicators of variability, which also takes into account the average of the set of analyzed data. This feature will help to better compare the evolution of the studied variables with each other.

Subsequently, we examine the relationships of Ratio1-3 with respect to the socio-economic level of the regions expressed by four indicators: Average disposable household income (DHI), Regional gross domestic product per capita (RegGDP), Unemployment rate (UR) and Enterprises by economic activities (SK NACE Rev. 2; Enterprises). The choice of socio-economic indicators was influenced by the scientific works of several authors (Matlovič, Matlovičová, 2005; Sloboda, 2006; Samson, 2008; Hrabovská, 2012; Hamada, Kasagranda, 2014; Chomjaková, Kožiak, Daxnerová, Giertl, 2017 etc.), as well as their relevance to the examined taxation ratios and, last but not least, their availability.

We present the socio-economic level of Slovak regions through maps of the Slovak Republic and the considered regions, where individual levels are highlighted by shading of regions (see Figure 9 and 10). For this purpose, we have introduced a new composite socio-economic index, obtained by the weighted sum method. The original values of each socio-economic indicator were arranged in descending order, while the highest value of the original indicator was evaluated by 8 points, the lowest by 1 point. In the case of UR indicator, the aim is to achieve the smallest possible value, so we used the opposite scoring and the composite indices for each region were created by summing of these points (we did not take into account different weights of the considered indicators).

For clarity, in Table 1 we present the descriptive characteristics of the considered socioeconomic indicators for 2010 and 2019.

Table 1: Descriptive characteristics of socio-economic indicators for 2010 and 2019

\begin{tabular}{|l|rrrrc|}
\hline Indicators & Minimum & Maximum & Mean & Median & Standard Deviation \\
\hline DHI_2010 & 491.8 & 734.1 & 569.6 & 562.1 & 72.5 \\
RegGDP_2010 & 7065.7 & 31152.8 & 12923.3 & 10491.7 & 7610.2 \\
UR_2010 & 4.6 & 18.9 & 12.3 & 11.3 & 5.1 \\
Enterprises_2010 & 11854.0 & 49600.0 & 17875.1 & 13324.0 & 12852.2 \\
DHI_2019 & 627.1 & 860.9 & 714.7 & 712.3 & 71.0 \\
RegGDP_2019 & 10604.5 & 39704.5 & 17488.2 & 14289.6 & 9307.9 \\
UR_2019 & 2.6 & 8.2 & 4.8 & 3.6 & 2.3 \\
Enterprises_2019 & 19508.0 & 82645.0 & 30877.8 & 24192.0 & 21044.3 \\
\hline
\end{tabular}

Source: Authors 


\section{Results and Discussion}

The results of the ratio indicators of taxation in the considered years are presented as a whole, from the point of view of the Slovak Republic and the NUTS III regions in the Slovak Republic. In the Figure 1, we observed a slight decrease in the total share indicators Ratio 1-3 for the Slovak Republic during the considered period. In 2010, their values ranged from 25 to $30 \%$, in 2019 they fell from 19.7 to $25.39 \%$. In other words, in the case of local taxes, there has been a declining trend in the share of resources from local government taxes in total tax revenues, and at the same time they represent a declining share in covering current expenditures. Relatively the smallest fluctuations were shown by the Ratio 3 indicator, which maintained values on average 25.5\% (standard dev. of 1.8\%). Due to the construction of indicators, their development (decline) was mainly influenced by the faster growth rate of local government revenues from share tax (compared to local tax revenues), that are significant part of Slovak local governments' tax revenues, which also allowed higher use of current expenditures.

Figure 1: Development of taxation indicators for the SR

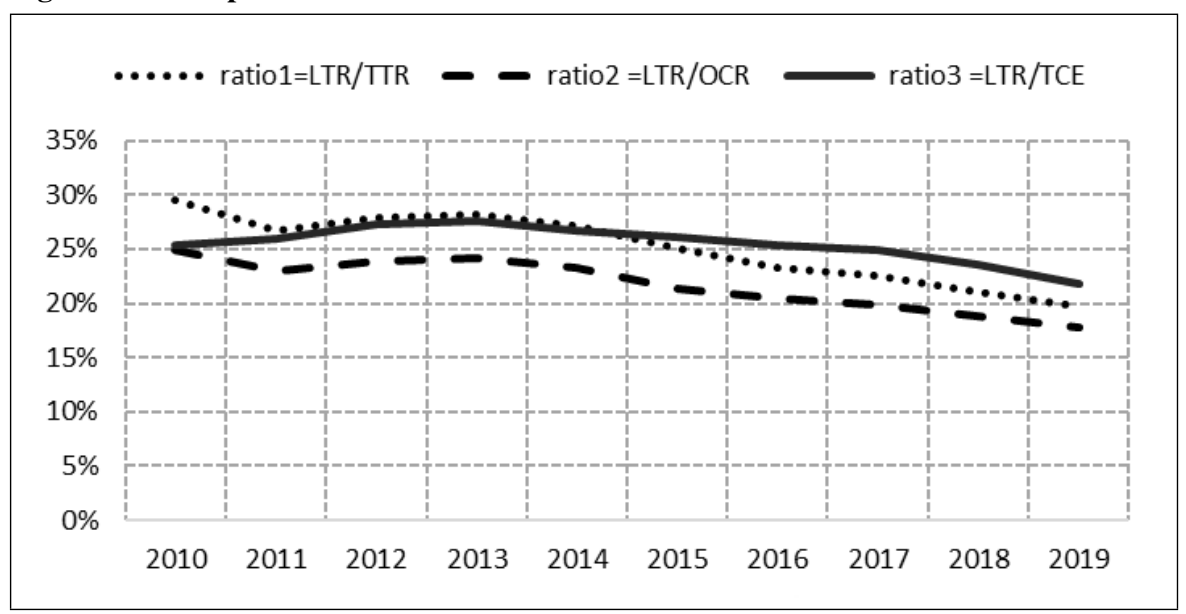

Source: Authors

The development of the share of local taxes in the total tax revenues of local governments (Ratio 1) in the years 2010 to 2019 and the range of its values at the beginning and end of the observed period are presented in Figure 2 and 3. We observed a decrease in its values in all regions, from an average value of $29.8 \%$ in 2010 (standard dev. $7.3 \%$ ) to an average value of $19.96 \%$ (standard dev. 5.0\%) in 2019 (on average decreased by $4.4 \%$ per year). This trend is slightly out of step in 2012, where we recorded a slight increase in the values of all local governments compared to 2011. This fact was due to the generally higher growth rate of local tax revenues (especially property taxes) compared to a more modest growth of share tax revenues in 2012 compared to 2011. In 2011, on the other hand, compared to 2010, the growth rate of share tax revenues was higher than the growth rate of local tax revenues. The highest values of the indicator were reported by the local 
governments of the BA region, followed by other regions of western Slovakia TT, NT and TN. The lowest values are reported by local governments located in the PO, ZA and BB region. The trend of smaller values of the Ratio1 indicator in the direction from the west to the east of the country is excluded by the local governments of the KE and ZA region, whose economies around the regional centres are strongly focused on the automotive, steel and IT industries.

Figure 2: Ratio1 for Slovak regions in the observed period

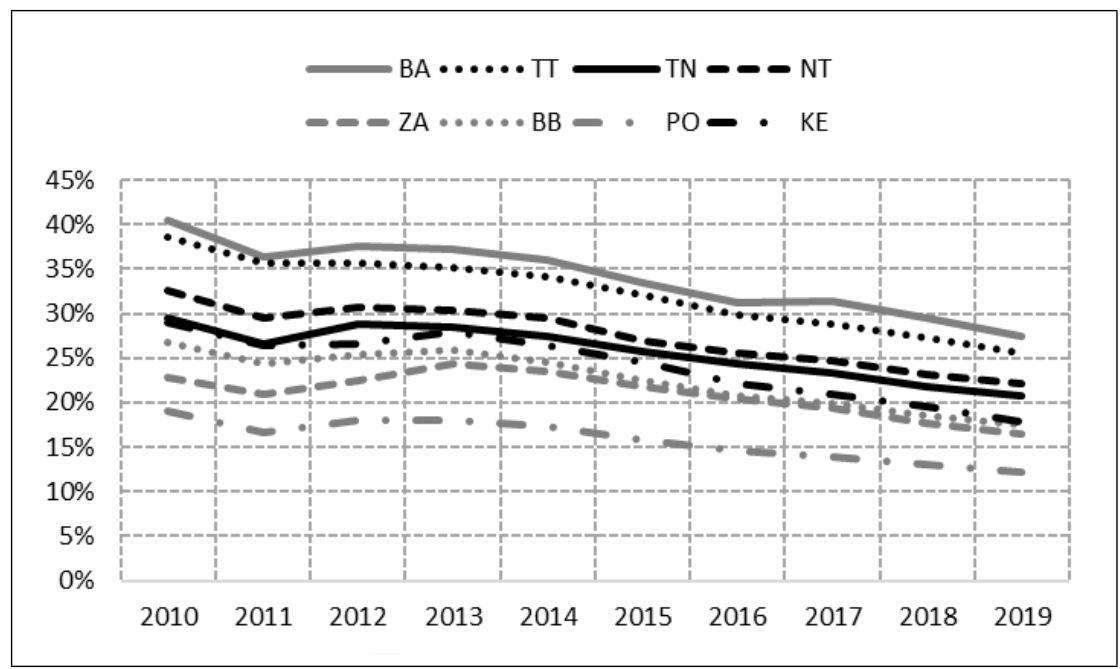

Source: Authors

Figure 3: Range of Ratio1 values in 2010 and 2019

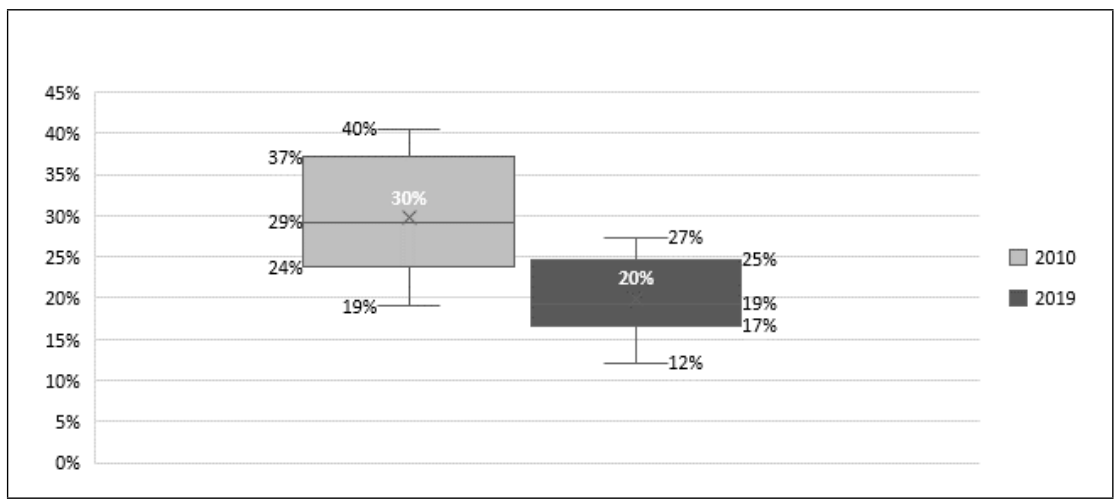

Source: Authors 
The results of the indicator monitoring the share of local taxes in own current income showed a similar course (Ratio2; see Figure 4 and 5). We observed a decrease in its values in all regions with slight fluctuations, from an average value of $25.1 \%$ (standard dev. 6\%) in 2010 to an average value of $17.9 \%$ (standard dev. 4.3\%) in 2019 (on average decreased by $3.7 \%$ per year). Year 2015 was beyond this trend; we recorded a more significant decrease in its values in the local governments of the BA region compared to 2014. The highest values of the indicator were again reported by the local governments of the BA region, followed by other regions of western Slovakia TT, NT and TN. The lowest values were again reported by local governments located in the eastern half of the Slovak Republic $\mathrm{PO}, \mathrm{ZA}$ and $\mathrm{BB}$ region.

Figure 4: Ratio2 for Slovak regions in the observed period

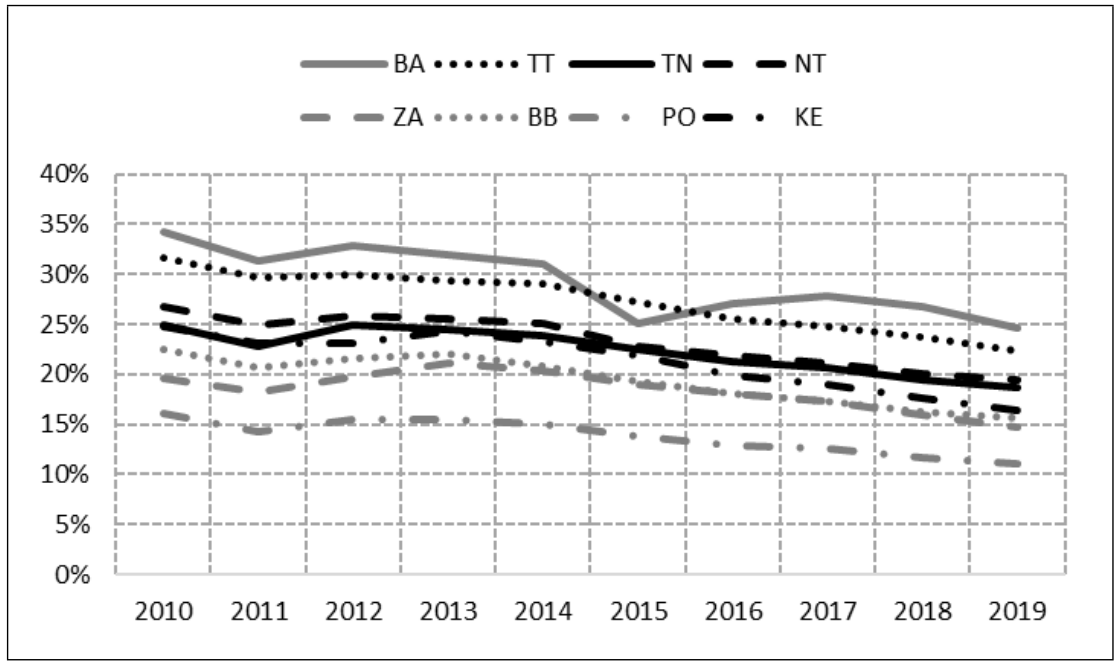

Source: Authors

Figure 5: Range of Ratio2 values in 2010 and 2019

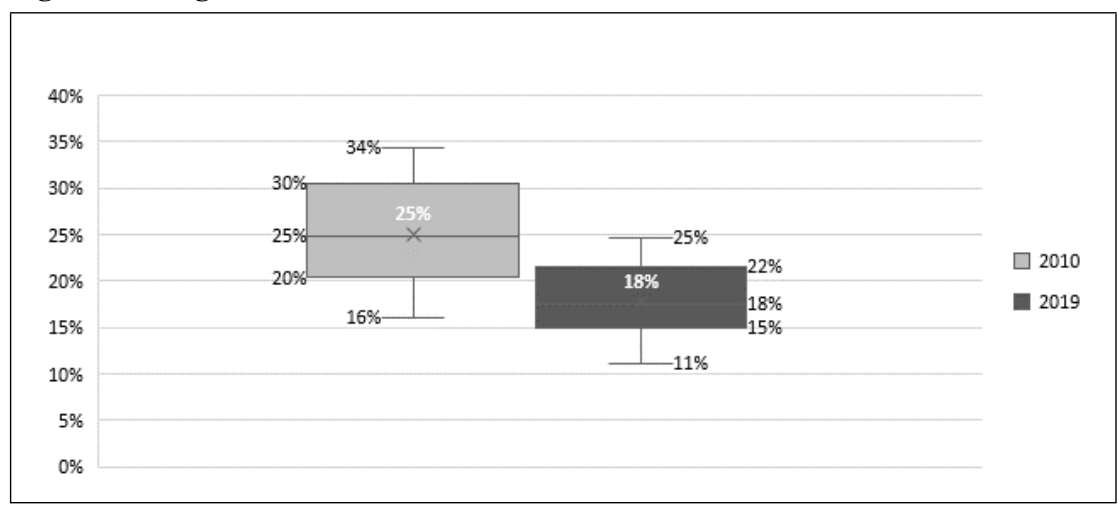

Source: Authors 
Figure 6 illustrates that the indicator of the share of local taxes in total expenditure (Ratio3) had a relatively balanced value in the observed period. The change was in the order of the regions of western Slovakia, where the highest values were achieved by the local governments of the TT region, followed by the local governments in the BA, TN and NT regions. The ranking of regions in the eastern half of the Slovak Republic with the lowest values was maintained; $\mathrm{PO}, \mathrm{BB}, \mathrm{ZA}$ and $\mathrm{KE}$ region. The range of values of this indicator at the beginning and end of the observed period (see Figure 7) did not change significantly; in 2010 the average value was $25.7 \%$ (standard dev. 5.9\%), in $201922.2 \%$ (standard dev. $5.6 \%$ ), on average decreased by $1.7 \%$ per year. This points to a downward trend in the share of local taxes to cover total expenditure by local governments.

Figure 6: Ratio3 for Slovak regions in the observed period

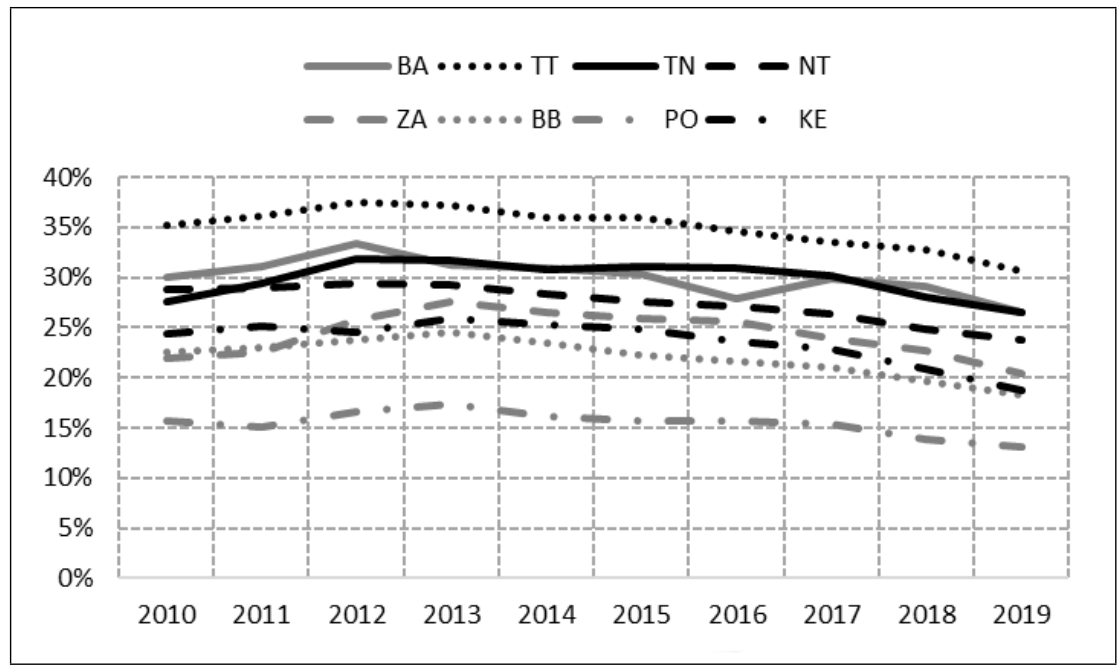

Source: Authors

Figure 7: Range of Ratio3 values in 2010 and 2019

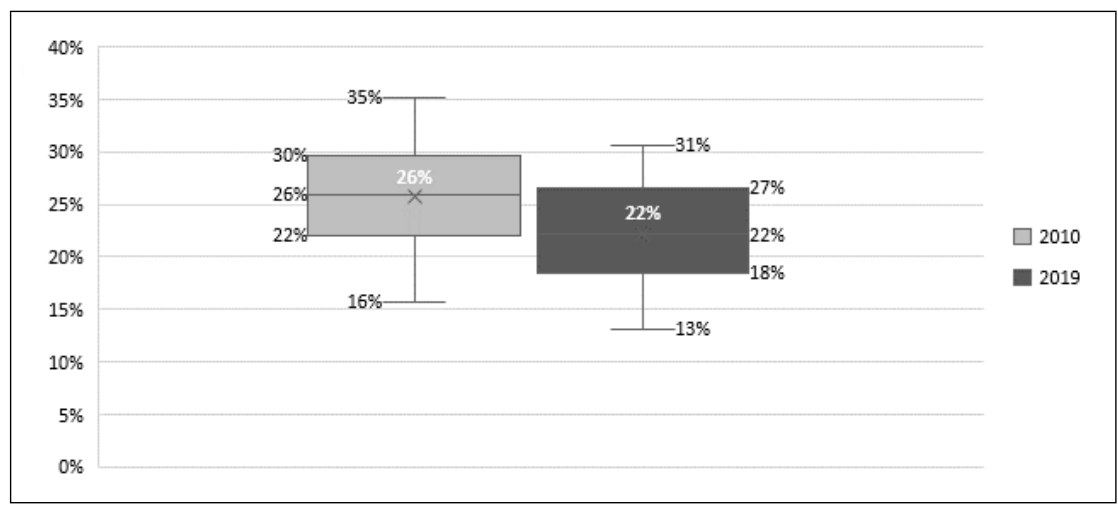

Source: Authors 
Figure 8 illustrates disparities in the development of indicators of taxation Ratio1-3 of local governments in the observed period within the NUTS III regions expressed by the coefficient of variation. The coefficient of variation of all indicators had a relatively balanced course at the level of $20-25 \%$, which indicates relatively significant regional differentiations. The decrease in interregional differences in the share of revenues from local taxes in own current revenues (Ratio2) in 2015 was caused by a more significant decrease in the values of this indicator in local governments in the BA region. The given development caused a higher year-on-year increase, especially in income from business and ownership of property and income from share tax in local governments of the BA region in 2015 compared to 2014.

Figure 8: Regional disparities within the SR

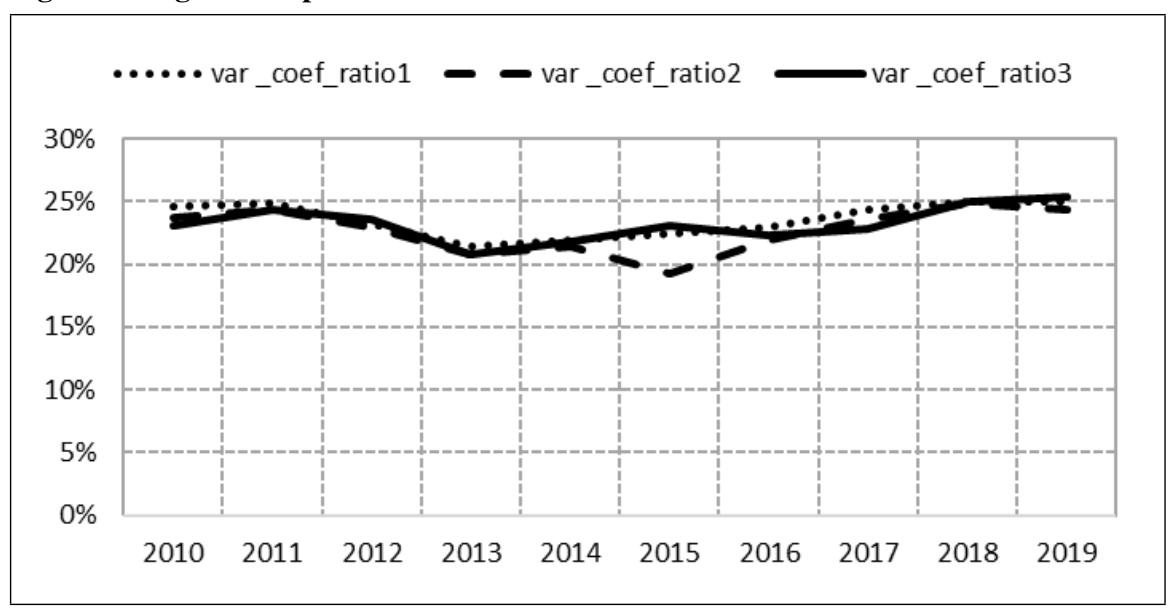

Source: Authors

The financing of local governments was also affected by the economic prosperity of the regions in which they are located. Due to the availability of socio-economic indicators at the regional level, we were limited by their choice, which consisted of indicators such as Average disposable household income (DHI), Regional gross domestic product per capita (RegGDP), Unemployment rate (UR) and Enterprises by economic activities (Enterprises) presents the results of the correlation analysis of the calculated Ratio 1-3 with selected socio-economic indicators at the beginning and end of the observed period (2010 and 2019). All indicators showed a medium to strong dependence (except for the Enterprises and Ratio3 indicators in both years) and their mutual correlations increased over time. The ratio indicators of local taxes correlated very strongly positively, especially with the indicator of average disposable income of households, and strongly negatively correlated with the rate of unemployment. When making the results general within the Slovak Republic, it seems that the more economically productive, attractive and low in unemployment the region, the greater the choice and willingness to pay local taxes in relation to total revenues and expenditure needs of local governments. 
Using the classification of the values of socio-economic indicators and their point evaluation, we calculated a new composite socio-economic index (Index) for the years 2010 and 2019 (beginning and end of the period considered) for each considered region (see details in methodology section).

Table 2 shows the correlations of selected socio-economic indicators and composite socioeconomic indices with tax ratios, Ratio1 to Ratio3, for 2010 and 2019.

Table 2: Correlations of monitored indicators for 2010 and 2019

\begin{tabular}{|l|cccccc|}
\hline Indicators & \multicolumn{1}{|c}{ Ratio1_2010 } & Ratio2_2010 & Ratio3_2010 & Ratio1_2019 & Ratio2_2019 & Ratio3_2019 \\
\hline DHI & 0.742 & 0.775 & 0.563 & 0.903 & 0.917 & 0.758 \\
RegGDP & 0.730 & 0.764 & 0.496 & 0.755 & 0.780 & 0.516 \\
UR & -0.736 & -0.746 & -0.737 & -0.806 & -0.788 & -0.900 \\
Enterprises & 0.591 & 0.629 & 0.292 & 0.582 & 0.613 & 0.278 \\
Index 2010 & 0.792 & 0.812 & 0.748 & & & \\
Index 2019 & & & & 0.875 & 0.871 & 0.773 \\
\hline
\end{tabular}

Source: Authors

Regional differentiations from the point of view of these two periods are illustrated in Figure 9 and 10. Higher socio-economic levels are reported by local governments located in the western part of the Slovak Republic (see legend). During the period under review, local governments in the NT region slightly improved their position (i.e. there was an improvement in economic performance), local governments in the $\mathrm{TN}$ region slightly worsened their position. The lowest values of the composite socio-economic index were reported in the local governments of the BB and PO regions, which maintained this position throughout the observed period. The strongest impact of local taxation of local governments in relation to the socio-economic situation was measured in the BA and TT regions (they show the highest values of the examined socio-economic indicators, as well as ratios of taxation in the whole period). The BA region is considered to be the most dynamically developing metropolitan region in Europe, the TT region immediately bordering it, and both are regions with a strong focus on the automotive, IT, and logistics industries. 
Figure 9: Socio-economic level of Slovakia regions in 2010

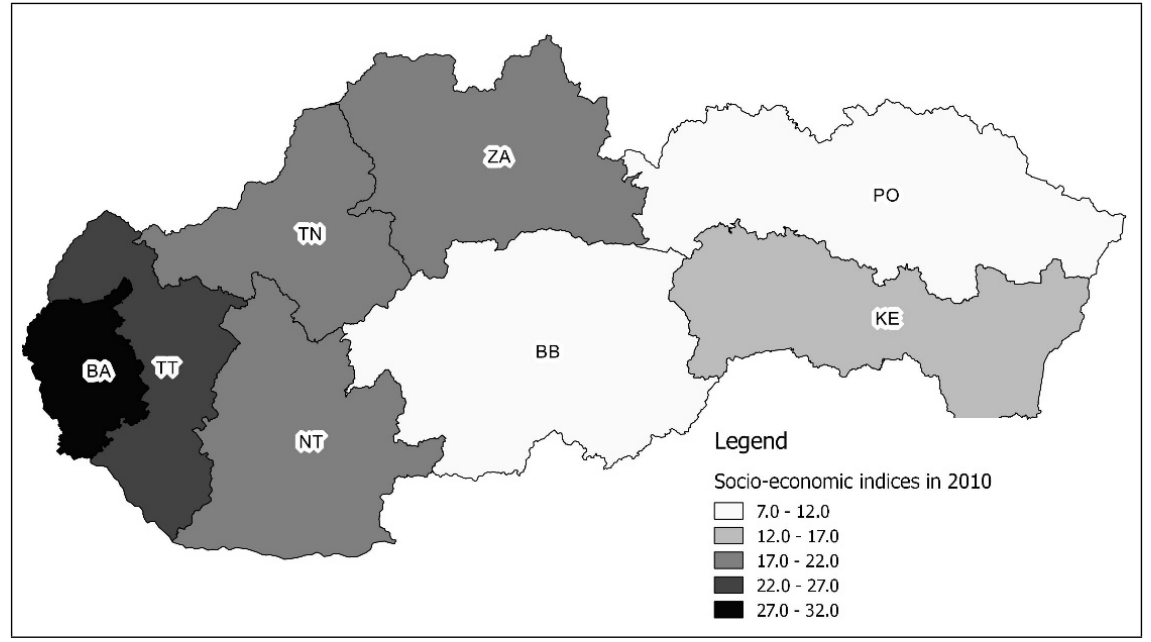

Source: Authors

Figure 10: Socio-economic level of Slovakia regions in 2019

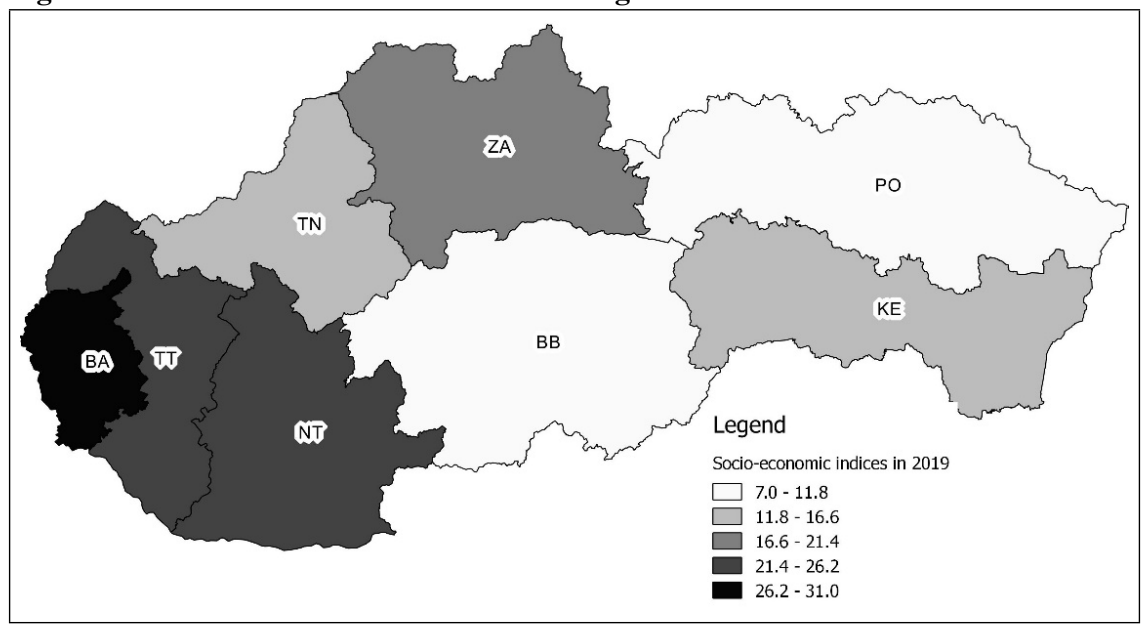

Source: Authors 


\section{Conclusion}

The aim of the article was to reveal regional differences in revenues from local taxation and to compare local government taxation ratios with selected socio-economic indicators within the NUTS III regions in the Slovak Republic. We observed a declining trend of the share of local taxes in the total tax revenues of local governments (Ratio1) in the years 2010 to 2019 in all regions. This was due to a higher growth rate of local tax revenues (especially property taxes) compared to a more modest growth in share tax revenues in 2012 compared to 2011. The highest values of the indicator Ratio1 were reported by the local governments of the BA region, followed by other regions of western Slovakia TT, NT and TN. The lowest values were reported by local governments located in the PO, ZA and BB region. The trend of smaller values of the Ratiol indicator in the direction from the west to the east of the country is excluded by the local governments of the KE and ZA region, whose economies around the regional centres are strongly focused on the automotive, steel and IT industries. The results of the indicator monitoring the share of local taxes in own current income showed a similar course (Ratio2). We observed a decrease in its values in all regions. The highest values of the indicator were again reported by the local governments of the BA region, followed by other regions of western Slovakia TT, NT and TN. The lowest values were reported by local governments located in the eastern half of the Slovak Republic - PO, ZA and BB region. The indicator of the share of local taxes in total expenditure (Ratio3) had a relatively balanced value in the observed period. The ranking of regions in the eastern half of the Slovak Republic with the lowest values was maintained; PO, BB, ZA and $\mathrm{KE}$ region. The results pointed to a downward trend in the share of local taxes to cover total expenditure by local governments in the observed period. The results of the evaluation of mutual relations between selected socio-economic indicators and three variants of tax revenues ratios of local governments in the Slovak Republic pointed to relatively large differences between NUTS III regions in Slovakia. It was relatively clear to see a deepening of regional differentiation between the western and northern part of Slovakia in comparison with the eastern and southern part of Slovakia. The willingness and determination of the amount of taxation of the population by local governments in individual NUTS III regions in the Slovak Republic in relation to the economic prosperity of the territory largely copies these tendencies and thus affects the volume of local government revenues generated. The worst results were achieved in the north-eastern part of the Slovak Republic. Investment incentives should be directed there, as improving the level of socio-economic development. The socio-economic attractiveness and prosperity of the regions have an impact on the share of local taxes in tax revenues and expenditures. It is up to the wider expert discussion whether it is appropriate to consider changing the ways of collecting local taxes in different territories depending on the socio-economic performance of the region in which they are located or to increase transfers from the national level. Modelling different scenarios of local tax collection and their impacts on the municipal economy may be the subject of further research. We realize that this study provides a specific view of regional differentiation of local government taxation in relation to selected socio-economic indicators, but provides findings that may be useful to the scientific community as well as to policymakers at various levels. 


\section{Acknowledgements}

The study was created with the support of the project VEGA 1/0151/18 "The impact of local taxes proceeds on performance of local government tasks in both economically developed and lagging regions in the context of Industry 4.0”.

\section{References}

Act no. 582/2004 Coll. on local taxes and local fees for municipal waste and small construction waste, as amended.

Ahmad, E., Tanzi, V., Gao, Q. (1995). Local Taxation in an International Perspective. Reforming China's Public Finances. Washington: International Monetary Fund.

Bilancie príjmov a výdavkov obcí 2010-2019 (Balances of revenues and expenditures of municipalities in 2010-2019). Bratislava: Ministry of Finance of the Slovak Republic.

Bird, R. M., Slack, E. (2002). Land and Property Taxation: A Review. World Bank Group. Retrieved January 12, 2021, from http://www1.worldbank.org/publicsector/decentralization/June2003Seminar/LandPropertyTaxation.pdf.

Čapková, S., Flaška, F. (2018). Financovanie územných samospráv v Slovenskej republike (Financing of local governments in the Slovak Republic). Vybrané kapitoly z veřejné správy a regionálního rozvoje (Selected Chapters from Public Administration and Regional Development). Prague: Professional Publishing. 44-59.

Flaška, F., Kološta, S., Bolcárová, P. (2014). Financial autonomy of municipalities in relation to economic performance in regions of the Slovak republic. SGEM conference on political sciences, law, finance, economics and tourism. Sofia: STEF92 Technology. 279-286.

Flaška, F., Rigová, Z. (2020). Importance of tax revenues in the budgets of Slovak local governments by NUTS III regions and by size categories of municipalities. Ekonomika a spoločnost' (Economy and society). Banská Bystrica: Belianum. 34-45.

Hamada, R., Kasagranda, A. (2014). Vybrané ekonomické, demografické ukazovatele, ukazovatele infraštruktúrnej vybavenosti a vzdelanostnej úrovne obyvatel'stva na meranie regionálnych disparít (Selected economic, demographic indicators, indicators of infrastructure facilities and educational level of the population for the measurement of regional disparities). Regionální rozvoj mezi teorií a praxí (Regional development between theory and practice). Hradec Králové: Civitas per Populi.

Hindls, R., Hronová, S., Seger, J. (2004). Statistika pro ekonomy (Statistics for economists). Prague: Professional Publishing.

Holm-Hadulla, F. (2020). Fiscal equalization and the tax structure. Regional Science and Urban Economics, 81, 1-19.

Hrabovská, Z. (2012). Komparácia samosprávnych krajov Slovenskej republiky na základe vybraných ukazovatelov regionálnej diferenciácie (Comparison of self-governing regions of the Slovak Republic on the basis of selected indicators of regional differentiation). Ekonomické aspekty v územnej samospráve II. (Economic aspects in territorial self-government II). Košice: Univerzita Pavla Jozefa Šafárika. 30-38. 
Chomjaková, M., Kožiak, R., Daxnerová, M., Giertl, G. (2017). Analýza vplyvu regionálnej politiky na existujúce regionálne rozdiely v SR na úrovni samosprávnych krajov (Impact analysis of regional policy on the existing regional differences in the SR at the level of self-governments). XX. international colloquium on regional sciences. Brno: Masaryk University. 83-90.

Kološta, S. (2016). Investigation of regional disparities in Slovakia in pre-crisis and crisis period. XIX. international colloquium on regional sciences. Brno: Masaryk University. 82-89.

Liptáková, K., Rigová, Z. (2021). Financial assumptions of Slovak municipalities for their active participation in regional development. Entrepreneurship and Sustainability Issues, 8(4), 312-330.

Matlovič, R., Matlovičová, K. (2005). Vývoj regionálnych disparít na Slovensku a problémy regionálneho rozvoja Prešovského kraja. Folia geographica, 2005, XLIII, 8, 66-88.

Outputs from DataCenter 2010-2019 databases. Available to order: https://www.datacentrum.sk/informaciebr-pre-verejnost/informacie/podla-zakona-2112000-zz-aa.html.

Rigová, Z., Flaška, F., Kološta, S. (2020). Regional differences in Slovak local governments' property tax revenues by NUTS III and LAU1 regions. Interpolis '20. Banská Bystrica: Belianum. 389-399.

Samson, Š. (2008). Rozdiely medzi regiónmi, ich vývoj a možnosti riešenia. National and regional economics VIII. Košice: Technická univerzita.

Sloboda, D. (2006). Slovensko a regionálne rozdiely. Teórie, regióny, indikátory, metódy (Slovakia and regional differences. Theories, regions, indicators, methods). Bratislava: M. R. Stefanik Conservative Institute.

Sopkuliak, A. (2017). Priestorové súvislosti v príjmoch a výdavkoch miestnej samosprávy na Slovensku (Spatial contexts in revenues and expenditures of local self-government in Slovakia). Journal of Geography, 69(2), 167-186.

Žárska, E., Ferčíková, V. (2015). Evaluation of economic potential of municipalities. XVIII. international colloquium on regional sciences. Brno: Masaryk University. 447-455. 